\title{
Phytoplankton extracellular release and bacterial growth: dependence on the inorganic $\mathrm{N}: \mathrm{P}$ ratio
}

\author{
Ingrid Obernosterer, Gerhard J. Herndl* \\ Dept of Marine Biology, Institute of Zoology, University of Vienna, Althanstr. 14, A-1090 Vienna, Austria
}

\begin{abstract}
Batch cultures of Chaetoceros affinis grown under nitrogen- $(\mathrm{N}: \mathrm{P}=5)$ and phosphorus$(\mathrm{N}: \mathrm{P}=100)$ limited conditions exhibited 30 and $100 \%$ higher rates of photosynthetic extracellular release (PER), respectively, than $C$. affinis grown under balanced nutrient conditions $(\mathrm{N}: \mathrm{P}=16)$. Inoculations of natural bacterial assemblages to PER derived from phytoplankton grown under these different nutrient regimes exhibited highest potential bacterial growth yields $(\sim 46 \%)$ on PER derived from balanced growth. Analysis of the dissolved monomeric (MCHO) and polymeric (PCHO) carbohydrate pool and of the dissolved free amino acid (DFAA) fraction of the PER indicated significantly higher specific release rates of these components for phytoplankton grown under P limitation. Based on the fluctuation of the MCHO, PCHO and DFAA pool in the batch cultures and on bacterial extracellular enzymatic activity (EEA) and bacterial growth yield we have evidence that under P-limited conditions bacteria are not taking up the available carbon efficiently. Bacteria growing on PER derived from $\mathrm{N}$-limited conditions exhibited high bacterial $\alpha$ - and $\beta$-glucosidase activity, while under P limitation low EEA was detectable. Extrapolating our results to the severely P-limited summer conditions of the Northern Adriatic Sea, we might conclude that P limitation provokes elevated PER in exponentially growing phytoplankton which is not utilized efficiently by the natural bacterial consortia. This would allow the PER to coagulate and eventually form mucilage.
\end{abstract}

KEY WORDS: Phytoplankton · Bacteria $\cdot$ Extracellular release $\cdot$ Nutrient limitation

\section{INTRODUCTION}

Photosynthetic extracellular release (PER) of phytoplankton has been intensively studied over the last 3 decades. It is now well known that PER is highest during the stationary phase of phytoplankton growth, but it has been disputed whether significant release also takes place in actively growing phytoplankton cells (Fogg 1966, Hellebust 1974, Sharp 1977, Mague et al. 1980, Myklestad et al. 1989). There is also evidence that elevated PER occurs under conditions of nutrient limitation (Myklestad \& Haug 1972, Myklestad 1977, Fogg 1983, Lancelot 1983, Watanabe 1980). Moreover, high-molecular-weight material appears to be relatively common among the compounds released (Nalewajko \& Schindler 1976, Saunders 1976, Iturriaga \& Zsolnay 1983). The tight coupling of primary produc-

\footnotetext{
- Addressee for correspondence
}

tion and bacterial utilization of phytoplankton extracellular release has been demonstrated by numerous authors (Iturriaga \& Hoppe 1977, Wiebe \& Smith 1977 , Larsson \& Hagström 1982, Wolter 1982, Bell 1983, Sell \& Overbeck 1992). For instance, studies performed over diel cycles have revealed patterns of bacterial activity similar to primary production: highest bacterial abundance and growth rates during the day and lowest at night (Fuhrman et al. 1985, Herndl \& Malacic 1987). Therefore, PER can be considered as one of the primary sources for bacterial growth.

In the Northern Adriatic Sea, excessive mucus production is a frequent phenomenon. This mucus basically consists of an amorphous, mucopolysaccharide matrix. During low turbulent conditions of the water column, this gelatinous material tends to aggregate to a size up to $2 \mathrm{~m}$ in diameter (Kaltenböck \& Herndl 1992). This microenvironment has been shown to be rich in inorganic and organic nutrients as well as in microorganisms (Alldredgre \& Silver 1988, Herndl 1988, Kalten- 
böck \& Herndl 1992). In 1991, occurrence of marine snow coincided with a high atomic ratio of inorganic nitrogen versus phosphorus (mean of 70 ; Kaltenböck \& Herndl 1992) indicating severe P limitation.

Since marine snow in the Northern Adriatic Sea is thought to be predominantly of phytoplankton origin (Degobbis 1989), we hypothesized that large amounts of PER are released from phytoplankton under Plimited primary production. This PER released under P-limited conditions was further hypothesized to be incorporated into bacteria with a lower efficiency than that produced under either $\mathrm{N}$ limitation or under balanced nutrient supply. Due to low bacterial utilization, PER might accumulate and eventually form mucilage during periods of appropriate physical conditions of the water column in the Northern Adriatic Sea.

\section{MATERIALS AND METHODS}

Experimental procedure. The experimental procedure is outlined in Fig. 1. Briefly, phytoplankton cultures were grown together with a natural bacterial inoculate under different $\mathrm{N}$ :P ratios. In the exponential and stationary growth phase particulate and dissolved primary production were measured. Concurrently, samples for dissolved carbohydrates and free amino acids of the PER were taken. The filtered and acidified radiolabeled dissolved organic carbon produced by phytoplankton $\left({ }^{14} \mathrm{C}\right.$-PER) from each treatment $(5 \mathrm{ml})$ was mixed with $40 \mathrm{ml}$ of artificial seawater in acidrinsed $125 \mathrm{ml}$ glass flasks. The $\mathrm{pH}$ was adjusted to 7.8 with $0.1 \mathrm{~N} \mathrm{NaOH}$. Then $5 \mathrm{ml}$ of the bacterial assemblage from the specific phytoplankton cultures $(0.8 \mu \mathrm{m}$ filtered) were incubated for $24 \mathrm{~h}$; thereafter, samples were taken for estimating bacterial growth rates using the leucine incorporation assay. This transfer of bacteria from nutrient-amended conditions to nutrientdepleted regimes is aimed to mimic water parcels being diluted with oligotrophic waters from the Middle Adriatic as they flow from the eutrophic western part eastward across the Northern Adriatic Sea.

Phytoplankton culture conditions. Batch cultures of the diatom Chaetoceros affinis (Culture Collection of the Dunstaffnage Marine Research Laboratory) were used. This diatom was chosen because of its widespread occurrence and abundance in the Northern Adriatic Sea. Stock cultures were maintained in a $f / 2$ medium (Guillard \& Ryther 1962). For the experiments, non-axenic phytoplankton cultures were prepared with varying $N: P$ ratios (Table 1 ). To inoculate the experimental cultures, cells from cultures grown in the corresponding medium were taken in the exponential growth phase (Myklestad 1977) and re-inoculated together with $10 \mathrm{ml}$ of $0.8 \mu \mathrm{m}$ filtered natural bacterial

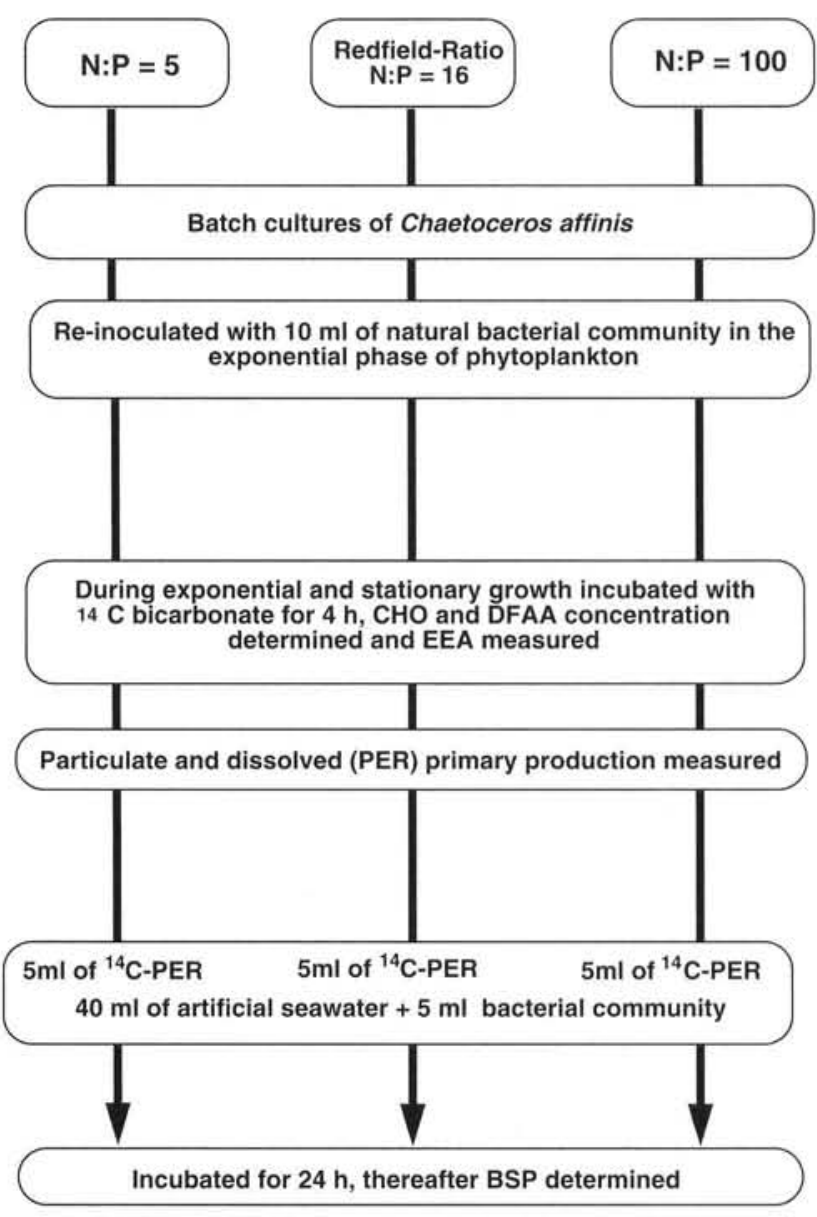

Fig. 1. Outline of the experimental setup. CHO: (dissolved) carbohydrates; DFAA: dissolved free amino acids; EEA: extracellular enzymatic activity; PER: photosynthetic extracellular release; BSP: bacterial secondary production. Further explanation in text

consortia collected from the Northern Adriatic Sea off Rovinj (Croatia); filtration of the bacterial consortia was performed immediately before inoculation. All media were in artificial seawater (Parsons et al. 1984). The continuously stirred cultures were grown at $22^{\circ} \mathrm{C}$ in 11 Erlenmeyer flasks containing 11 of medium and kept at a light:dark cycle of $16: 8 \mathrm{~h}$. For illumination, white cool light with a photosynthetic active radiation (PAR) of $180 \mu \mathrm{E} \mathrm{m}^{-2} \mathrm{~s}^{-1}$ was used.

Table 1. Initial nutrient concentrations in the different phytoplankton cultures used for the experiments

\begin{tabular}{|ccc|}
\hline $\mathrm{NO}_{3}{ }^{-}(\mu \mathrm{M})$ & $\mathrm{PO}_{4}{ }^{3-}(\mu \mathrm{M})$ & $\begin{array}{c}\mathrm{N}: \mathrm{P} \\
\text { (atomic ratio) }\end{array}$ \\
\hline 40 & 8 & 5 \\
40 & 2.5 & 16 \\
40 & 0.4 & 100 \\
\hline
\end{tabular}


To determine the growth phases of phytoplankton optical density (OD) of the phytoplankton cultures was measured spectrophotometrically at $550 \mathrm{~nm}$ wavelength. When OD doubled within $24 \mathrm{~h}$ an exponential growth phase was assumed; when OD remained constant, the culture reached stationary growth phase.

Chlorophyll a. The total biomass of phytoplankton present under different nutrient conditions was estimated by measuring the amount of chlorophyll $a$ (chl a) spectrophotometrically (Parsons et al. 1984).

Primary production and photosynthetic extracellular release. Primary production was measured by uptake of radiolabeled ${ }^{14} \mathrm{C}$-sodium bicarbonate and its subsequent conversion into organic compounds (Parsons et al. 1984). The percentage of PER was estimated using the method described by Lignell $(1990,1992)$.

Subsamples of each phytoplankton culture $(100 \mathrm{ml})$ were filled into acid-rinsed glass-stoppered flasks and $2 \mu \mathrm{Ci} \mathrm{Na}\left(\mathrm{H}^{14} \mathrm{CO}_{3}\right)_{2}$ (specific activity $2 \mathrm{mCi} \mathrm{mmol}^{-1}$, Amersham) were added. Incubation of duplicate light bottles and one dark control was performed at $180 \mu \mathrm{E}$ $\mathrm{m}^{-2} \mathrm{~s}^{-1}$ for $4 \mathrm{~h}$. Thereafter, subsamples were filtered onto $0.45 \mu \mathrm{m}$ pore size cellulose membrane filters (Millipore HA, $25 \mathrm{~mm}$ diameter filter) by applying a suction pressure not exceeding $20 \mathrm{mbar}$ in order to prevent leakage of $\mathrm{DO}^{14} \mathrm{C}$ from the cells. Filters were rinsed with $5 \mathrm{ml}$ of $0.2 \mu \mathrm{m}$ filtered seawater and exposed to fumes of concentrated $\mathrm{HCl}$ (for $10 \mathrm{~min}$ ) to remove inorganic carbon. Then the filters were dissolved in $1 \mathrm{ml}$ of ethylacetate (Loba Chemie, Vienna, Austria) and after $10 \mathrm{~min}, 8 \mathrm{ml}$ of scintillation cocktail (Insta-Gel, Packard) were added. A volume of $3 \mathrm{ml}$ of the filtrates was transferred to scintillation vials, acidified with $20 \mu \mathrm{l}$ concentrated $\mathrm{H}_{2} \mathrm{SO}_{4}$ and left open in a fume hood for $24 \mathrm{~h}$. After adding $7 \mathrm{ml}$ of scintillation cocktail, the samples were kept tightly capped for 14 to $16 \mathrm{~h}$ before radioactivity was measured in a liquid scintillation counter (Canberra Packard, Tricarb 2000) corrected for quenching by external standard ratio. In all primary productivity calculations dark values were subtracted from corresponding light values.

Bacterial density. Bacterial density was determined by acridine orange staining and epifluorescence microscopy on black polycarbonate Nuclepore $(0.2 \mu \mathrm{m}$ pore size, $25 \mathrm{~mm}$ diameter filter) membrane filters (Hobbie et al. 1977). Samples (5 ml) were fixed with $0.2 \mathrm{ml}$ of $0.2 \mu \mathrm{m}$ filtered, concentrated formalin and then stained with a few drops of an acridine orange solution $(0.2 \mu \mathrm{m}$ filtered) for $1 \mathrm{~min}$. After filtration, the filter was embedded in parafin oil and stored at $4{ }^{\circ} \mathrm{C}$ until counting using a Leitz Laborlux microscope equipped with a Ploemopak epiflourescence unit.

Bacterial secondary production. Bacterial secondary production (BSP) was estimated by adding ${ }^{3} \mathrm{H}$-leucine (specific activity $120 \mathrm{Ci} \mathrm{mmol}{ }^{-1}$, Amer- sham) to the subsample giving a final concentration of $10 \mathrm{nM}$ (Simon \& Azam 1989). Subsamples $(5 \mathrm{ml})$ were incubated in triplicates and 2 blanks in gammaradiated test tubes (Falcon, Inc.); blanks were fixed with concentrated formalin to give a final concentration of $4 \%(\mathrm{v} / \mathrm{v})$. After incubating for $30 \mathrm{~min}$, the samples were filtered onto $0.45 \mu \mathrm{m}$ cellulose nitrate filters (Millipore HA, $25 \mathrm{~mm}$ diameter filter) and extracted twice with $10 \mathrm{ml}$ ice-cold $5 \%$ trichloracetic acid (Sigma Chemicals) for $5 \mathrm{~min}$. The filters were dissolved in $1 \mathrm{ml}$ ethylacetate and after $10 \mathrm{~min}, 8 \mathrm{ml}$ of scintillation cocktail were added and radioassayed after 14 to $16 \mathrm{~h}$. Previous tests have shown that the use of cellulose-nitrate filters for BSP measurements result in higher counting efficiency and lower blanks as compared to polycarbonate filters, probably because polycarbonate filters do not dissolve completely in ethylacetate or scintillation cocktail. Furthermore we did not find differences in BSP measurements between $0.2 \mu \mathrm{m}$ and $0.45 \mu \mathrm{m}$ cellulose-nitrate filters. A conversion factor of $0.108 \times 10^{18}$ cells produced $\mathrm{mol}^{-1}$ leucine incorporated was used (Kirchman 1992). This conversion factor has also been shown to be representative for bacterial consortia of the Northern Adriatic Sea (Obernosterer et al. unpubl.). For the conversion of cell number into carbon biomass, a carbon content per cell of $20 \mathrm{fg}$ was assumed (Lee \& Fuhrmann 1987).

Extracellular enzymatic activity. Extracellular enzymatic activity (EEA) was estimated using fluorogenic substrate analogs as described by Hoppe (1983). The 4-methylumbelliferyl $\alpha$-D-glucopyranoside $(\alpha$ MUF) and the 4-methylumbelliferyl $\beta$-D-glucopyranoside ( $\beta$-MUF) were used to estimate $\alpha$-glucosidase and $\beta$-glucosidase activity, respectively. According to Hoppe et al. (1988), cleavage of $\alpha$-MUF and $\beta$-MUF reflects hydrolysis of $\alpha$ - and $\beta$-glucosidic bonds, respectively. Stock solutions were prepared in cellosolve (Sigma Chemicals) and stored at $-20^{\circ} \mathrm{C}$. Working solutions of $\alpha$ - and $\beta$-MUF were prepared with double-distilled water and added to $3 \mathrm{ml}$ of sample to give a final concentration of $2.5 \mu \mathrm{M}$. In previous experiments different substrate concentrations have been tested; a concentration of $2.5 \mu \mathrm{M}$ was found to be sufficient to ensure maximum fluorescent yield (data not shown). In order to calibrate fluorophore release, standards were made with known concentrations of 4-methylumbelliferone (MU). An incubation period of 30 to 45 min usually resulted in a sufficient increase in fluorescence. Fluorescence was measured against a sample blank with a Jasco 820 spectrofluorometer at $360 \mathrm{~nm}$ excitation and $444 \mathrm{~nm}$ emission wavelength.

Dissolved organic matter. Samples for dissolved carbohydrates and free amino acids were filtered 
through precombusted $\left(480^{\circ} \mathrm{C}\right.$ for $\left.4 \mathrm{~h}\right)$ Whatman GF/F glass fiber filters, sealed in precombusted glass ampoules and immediately frozen at $-20^{\circ} \mathrm{C}$. Within $2 \mathrm{mo}$, dissolved monomeric (MCHO) and total carbohydrates (TCHO) were determined following the 3-methyl-2-benzothiazolinone hydrazone (MBTH) method by Johnson \& Sieburth (1977) and Burney \& Sieburth (1977), using a modified procedure to hydrolyze the samples (see also Pakulski \& Benner 1992). Briefly, samples for TCHO analysis were acidified with $36 \% \mathrm{HCl}(1: 1, \mathrm{v} / \mathrm{v})$ and kept at $110^{\circ} \mathrm{C}$ for $24 \mathrm{~h}$. After hydrolysis, samples were evaporated at $5^{\circ} \mathrm{C}$ at 200 mtorr and the resulting powder stored in a desiccator not longer than $12 \mathrm{~h}$. Before analysis, the dried samples were re-dissolved in the same volume of double-distilled water. Complete dissolution of salt crystals was achieved by ultrasonication (Labsonic, Brown) for 2 min. After neutralizing with $0.05 \mathrm{~N} \mathrm{NaOH}$, samples were analyzed in the same way as MCHO. Dissolved free amino acids (DFAA) were determined by OPA derivatization and HPLC analysis (Mopper \& Lindroth 1982).

We assumed that TCHO and DFAA comprised a significant fraction of DOM released by phytoplankton; from the concentrations of MCHO and DFAA we calculated their $\mathrm{C}$ and $\mathrm{N}$ content in order to obtain a rough approximation of the $C: N$ ratio of the readily utilizable DOM-pool present.

Statistical analysis. Unless stated otherwise, the Wilcoxon test for matched pairs was used to test treatment effects on variables. Statistics were performed with SYSTAT 5.2 (Wilkinson 1990).

\section{RESULTS}

\section{Primary production and photosynthetic extracellular release}

Phytoplankton grown under different $\mathrm{N}: \mathrm{P}$ ratios showed similar growth curves (Fig. 2). Phytoplankton grown in the $\mathrm{N}: \mathrm{P}=100$ medium reached significantly lower OD during stationary growth ( $\mathrm{p}<0.05, \mathrm{n}=6$ ) than phytoplankton grown in media of $\mathrm{N}: \mathrm{P}=5$ and $\mathrm{N}: \mathrm{P}=16$ (Fig. 2).

During exponential growth, specific productivity in $\mu \mathrm{g} \mathrm{C} \mu \mathrm{g}^{-1} \mathrm{chl} \mathrm{a} \mathrm{h}^{-1}$ was found to be higher (though not significantly) for phytoplankton grown in the $\mathrm{N}: \mathrm{P}=5$ and $\mathrm{N}: \mathrm{P}=16$ media than for phytoplankton grown in the $\mathrm{N}: \mathrm{P}=100$ medium (Table 2). During stationary phase, specific productivity ranged from 1 to $1.2 \mu \mathrm{g} \mathrm{C} \mathrm{gg}^{-1} \mathrm{chl} \mathrm{a} \mathrm{h}^{-1}$ and was found to be significantly lower in all treatments compared to specific productivity of the exponential growth $(\mathrm{p}<0.05$, $\mathrm{n}=6)$.

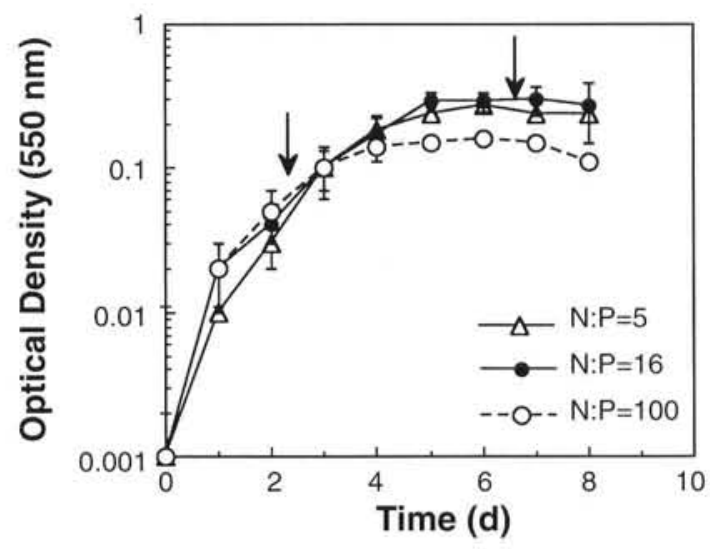

Fig. 2, Growth curves of phytoplankton batch cultures under varying $\mathrm{N}: \mathrm{P}$ ratios as revealed by optical density measurements. Arrows indicate date of sampling

The proportion of PER as percentage of total primary production (i.e. particulate production + PER) increased in all treatments from exponential to stationary growth, but was highly variable among different experiments. During exponential growth, the percentage of PER in the $\mathrm{N}: \mathrm{P}=100$ culture significantly exceeded the percentage of PER of phytoplankton grown in the $\mathrm{N}: \mathrm{P}=5$ and $\mathrm{N}: \mathrm{P}=16$ cultures by $\sim 60 \%$ $(\mathrm{p}=0.045, \mathrm{n}=6)$ and $\sim 100 \%(\mathrm{p}=0.009, \mathrm{n}=6)$, respectively (Table 2 ). In the stationary phase, a significantly higher percentage of PER was only detectable for phytoplankton grown in the $\mathrm{N}: \mathrm{P}=100$ medium $(\mathrm{p}=$ $0.04, \mathrm{n}=6$ ) as compared to the $\mathrm{N}: \mathrm{P}=16$ medium (Table 2). During exponential growth, PER in terms of carbon and \% PER was higher in the $\mathrm{N}: \mathrm{P}=100$ medium. During stationary growth, highest PER in terms of carbon were observed for phytoplankton in the $\mathrm{N}: \mathrm{P}=16$ medium while the $\% \mathrm{PER}$ was lowest (Table 2), whereas in the $\mathrm{N}: \mathrm{P}=100$ medium the highest \% PER coincided with low absolute PER rates (Table 2).

Table 2. Specific productivity, photosynthetic extracellular release (PER) and PER as \% of total primary production under different growth regimes; means $\pm \operatorname{SE}(n=6)$

\begin{tabular}{|cccc|}
\hline N:P ratio & $\begin{array}{c}\text { Specific prod. } \\
\left(\mu \mathrm{g} \mathrm{C} \mu \mathrm{g}^{-1} \mathrm{chl} \mathrm{a} \mathrm{h}^{-1}\right)\end{array}$ & $\begin{array}{c}\text { PER } \\
\left(\mu \mathrm{g} \mathrm{C} \mathrm{l}^{-1} \mathrm{~h}^{-1}\right)\end{array}$ & $\%$ PER \\
\hline \multicolumn{3}{c}{ Exponential phase } \\
5 & $4.6 \pm 1.9$ & $7.0 \pm 0.9$ & $21 \pm 9$ \\
16 & $4.4 \pm 1.4$ & $7.6 \pm 2.5$ & $15 \pm 6$ \\
100 & $3.4 \pm 1.1$ & $10.2 \pm 2.6$ & $29 \pm 10$ \\
Stationary phase & & \\
5 & $1.0 \pm 0.1$ & $11.9 \pm 3.6$ & $30 \pm 8$ \\
16 & $1.0 \pm 0.4$ & $12.3 \pm 5.6$ & $29 \pm 8$ \\
100 & $1.2 \pm 0.3$ & $6.7 \pm 1.8$ & $37 \pm 9$ \\
\end{tabular}




\section{Carbohydrate and amino acid concentrations of the PER released}

The development of dissolved carbohydrate concentrations in the phytoplankton cultures showed that exudation took place during all phases of growth. Monomeric (MCHO) and polymeric $(\mathrm{PCHO}$; i.e. $\mathrm{TCHO}-\mathrm{MCHO}$ ) carbohydrate concentrations did not differ significantly among the 3 treatments and only $\mathrm{MCHO}$ concentrations increased significantly from exponential to stationary growth in the $\mathrm{N}: \mathrm{P}=100$ treatment $(\mathrm{p}=0.046, \mathrm{n}=7)$.

Related to chl $a$, however, distinct patterns were detectable for both $\mathrm{MCHO}$ and PCHO (Fig. 3a, b). During stationary growth significantly higher $\mathrm{MCHO}$ concentrations per chl a were detectable in the $\mathrm{N}: \mathrm{P}=100$ medium compared to the $\mathrm{N}: \mathrm{P}=5(\mathrm{p}=0.021$, $\mathrm{n}=7)$ and $\mathrm{N}: \mathrm{P}=16(\mathrm{p}=0.009, \mathrm{n}=7)$ media, respectively (Fig. 3a); generally, PCHO exhibited similar patterns to $\mathrm{MCHO}$ and were also significantly higher in the $\mathrm{N}: \mathrm{P}=100$ medium compared to the $\mathrm{N}: \mathrm{P}=5(\mathrm{p}=0.047$, $\mathrm{n}=6)$ and $\mathrm{N}: \mathrm{P}=16(\mathrm{p}=0.013, \mathrm{n}=6)$ media, respectively (Fig. 3b).

DFAA concentrations ranged from 130 to $170 \mathrm{nM}$ during exponential phase and increased towards the
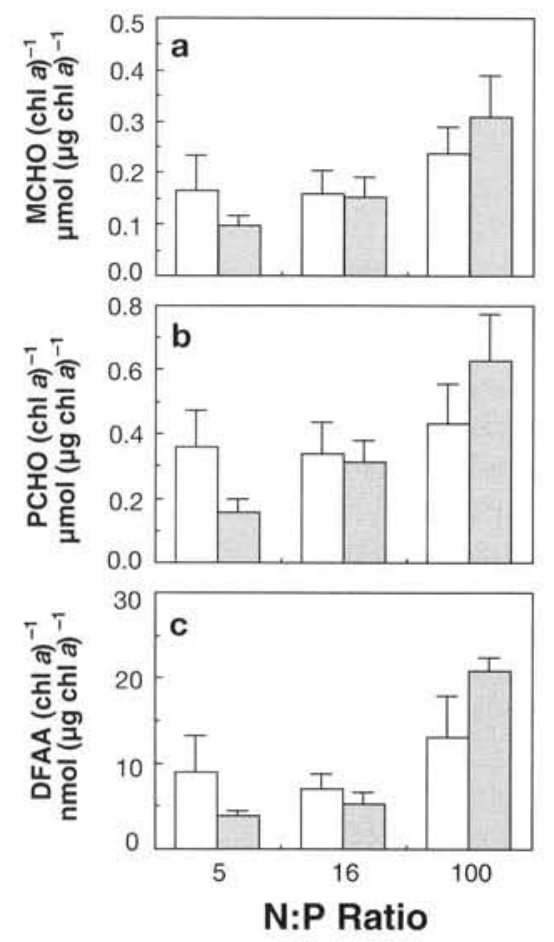

Fig. 3. (a) Specific monomeric carbohydrate (MCHO), (b) polymeric carbohydrate (PCHO) and (c) dissolved free amino acids (DFAA) concentrations in phytoplankton cultures of different N:P ratios and growth phases. Plain bars: exponential growth; shaded bars: stationary growth stationary phase to $300 \mathrm{nM}$ in the cultures grown in the $\mathrm{N}: \mathrm{P}=100$ medium. Significantly higher concentrations were found during stationary growth in the $\mathrm{N}: \mathrm{P}=100$ medium compared to the $\mathrm{N}: \mathrm{P}=5(\mathrm{p}=0.021, \mathrm{n}=6)$ and $\mathrm{N}: \mathrm{P}=16(\mathrm{p}=0.021, \mathrm{n}=6)$ media. Normalizing DFAA concentrations to chl a (nmol DFAA $\mu^{-1} \mathrm{chl}$ a), a 5fold higher specific DFAA production was detectable in the $\mathrm{N}: \mathrm{P}=100$ culture than in the cultures grown in the $\mathrm{N}: \mathrm{P}=5(\mathrm{p}=0.034, \mathrm{n}=6)$ and $\mathrm{N}: \mathrm{P}=16(\mathrm{p}=0.034, \mathrm{n}=$ 6 ) media during stationary growth (Fig. 3c).

As shown in Table 3, MCHO were highly positively correlated with $\mathrm{PCHO}$ in all treatments while neither $\mathrm{MCHO}$ nor PCHO were correlated with DFAA concentrations.

\section{Bacterial secondary production}

Mean BSP in bacterial batch cultures inoculated with PER from phytoplankton in exponential growth was similar for all PER derived from the 3 different nutrient conditions (Table 4), whereas BSP incubated with PER harvested in stationary phase revealed about $20 \%$ higher values for the $\mathrm{N}: \mathrm{P}=16$ and $\mathrm{N}: \mathrm{P}=100$ media compared to the $\mathrm{N}: \mathrm{P}=5$ medium (Table 4). No significant differences in BSP could be found among treatments and growth phases of phytoplankton. Bacterial turnover rates (BSP/biomass) exhibited highest rates in the PER derived from phytoplankton grown in the $\mathrm{N}: \mathrm{P}=5$ medium in the exponential phase, while bacterial turnover rates were similar when growing on PER derived from phytoplankton in stationary phase. Potential bacterial growth yields $(\%)$ were highest with PER from phytoplankton of the N:P=16 medium of exponential growth (Table 4). PER derived from stationary phase increased potential growth yields of the $N: P=16$ and $N: P=100$ media, while PER from the $\mathrm{N}: \mathrm{P}=5$ medium decreased potential growth yields.

Table 3. Pearson's Correlation matrix of different DOM fractions under varying $\mathrm{N}: \mathrm{P}$ ratios; data from exponential and stationary phase are pooled

\begin{tabular}{|lrccc|}
\hline DOM fraction & N:P & r & $n$ & $p$ \\
\hline MCHO:PCHO & 5 & 0.981 & 8 & 0.001 \\
& 16 & 0.920 & 8 & 0.001 \\
PCHO:DFAA & 100 & 0.878 & 8 & 0.004 \\
& 5 & 0.085 & 6 & 0.872 \\
MCHO:DFAA & 16 & 0.698 & 6 & 0.123 \\
& 100 & 0.801 & 6 & 0.055 \\
& 5 & 0.216 & 7 & 0.642 \\
& 16 & 0.632 & 7 & 0.128 \\
& 100 & 0.584 & 7 & 0.169 \\
\hline
\end{tabular}


Table 4. Bacterial secondary production (BSP), bacterial turnover rates $(\mu) \mathrm{d}^{-1}$ and potential bacterial growth yield [based on bacterial carbon produced $\mathrm{d}^{-1}$ and PER (in $\mu \mathrm{g} \mathrm{C} \mathrm{l}^{-1} \mathrm{~d}^{-1}$ ) derived from Table 2; it was assumed that all the PER is used as a substrate for bacterial growth]. Number of experiments given in parenthesis; means $\pm \mathrm{SE}$

\begin{tabular}{|cccc}
\hline N:P ratio & BSP $\left(\mu \mathrm{C} \mathrm{Cl}^{-1} \mathrm{~d}^{-1}\right)$ & $\mu\left(\mathrm{d}^{-1}\right)$ & $\begin{array}{r}\text { Potential gro } \\
\text { yield }(\%)\end{array}$ \\
\hline \multicolumn{5}{|c}{$\begin{array}{c}\text { Exponential phase } \\
5\end{array}$} & $47.2 \pm 5.6$ & $2.1 \pm 1.6$ & $38 \pm 5$ \\
& $(\mathrm{n}=8)$ & $(\mathrm{n}=3)$ & $(\mathrm{n}=5)$ \\
16 & $46.9 \pm 6.5$ & $1.1 \pm 0.5$ & $46 \pm 12$ \\
& $(\mathrm{n}=8)$ & $(\mathrm{n}=3)$ & $(\mathrm{n}=5)$ \\
100 & $47.7 \pm 9.6$ & $1.3 \pm 0.5$ & $33 \pm 9$ \\
& $(\mathrm{n}=8)$ & $(\mathrm{n}=3)$ & $(\mathrm{n}=5)$
\end{tabular}

Stationary phase

$\begin{array}{rccc}5 & 50.1 \pm 10 & 0.8 \pm 0.2 & 22 \pm 12 \\ & (\mathrm{n}=6) & (\mathrm{n}=3) & (\mathrm{n}=5) \\ 16 & 63.8 \pm 8.4 & 0.7 \pm 0.2 & 53 \pm 25 \\ & (\mathrm{n}=6) & (\mathrm{n}=3) & (\mathrm{n}=5) \\ 100 & 61.9 \pm 8.9 & 1 \pm 0.4 & 56 \pm 18 \\ & (\mathrm{n}=6) & (\mathrm{n}=3) & (\mathrm{n}=5)\end{array}$

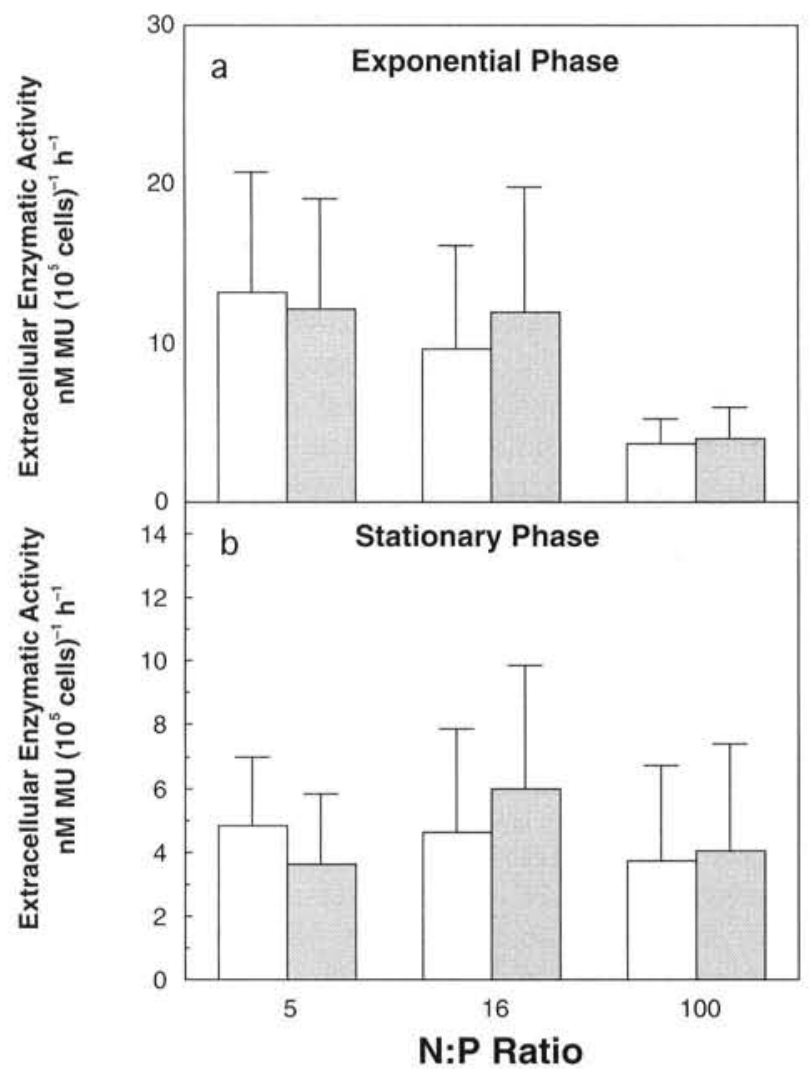

Fig. 4. Extracellular enzymatic activity of $\alpha$ - and $\beta$-glucosidase under varying $\mathrm{N}: \mathrm{P}$ ratios in (a) exponential and (b) stationary growth phase. Plain bars: $\alpha$-glucosidase activity; shaded bars: $\beta$-glucosidase activity

\section{Extracellular enzymatic activity}

Generally, $\alpha$-glucosidase activity was highly correlated with $\beta$-glucosidase activity under all nutrient conditions (Pearson's $r=0.99, p<0.001, n=10$ ). EEA varied from 0.2 to $39 \mathrm{nM}$ MU released $\left(10^{5}\right.$ bacterial cells $)^{-1} h^{-1}$. During exponential growth $\alpha$ - as well as $\beta$ glucosidase activity was found to be about 4 times higher in the $\mathrm{N}: \mathrm{P}=5$ and $\mathrm{N}: \mathrm{P}=16$ medium than in the $\mathrm{N}: \mathrm{P}=100$ medium $(\mathrm{p}<0.05, \mathrm{n}=7$ ) (Fig. 4a). During stationary phase, EEA decreased remarkably (Fig. 4b); yet enzymatic activity was significantly lower in the $\mathrm{N}: \mathrm{P}=100$ medium $(\mathrm{p}<0.05, \mathrm{n}=6)$ than in the $\mathrm{N}: \mathrm{P}=16$ medium.

As shown in Table $5, \alpha$ - and $\beta$-glucosidase activity correlated with DFAA concentrations of the PER derived from phytoplankton grown in the $\mathrm{N}: \mathrm{P}=5$ medium $(\mathrm{p}<0.001)$. EEA did not correlate with DFAA for the $\mathrm{N}: \mathrm{P}=16$ and $\mathrm{N}: \mathrm{P}=100$ media.

Highest $\alpha$ - and $\beta$-glucosidase activities coincided with lowest calculated $\mathrm{C}: \mathrm{N}$ ratios of the PER added to the bacterial batch cultures; this relationship was most pronounced for glucosidase activity in batch cultures to which PER from phytoplankton grown in $\mathrm{N}: \mathrm{P}=5$ medium was added (Fig. 5). With increasing $\mathrm{N}$ : P ratio of the medium in which the phytoplankton cultures were grown the relationship between the $\mathrm{C}: \mathrm{N}$ ratio of the readily utilizable DOM fraction of the PER and EEA became less pronounced (Fig. 5).

\section{DISCUSSION}

Recent investigations (Kaltenböck \& Herndl 1992) indicate high $\mathrm{N}: \mathrm{P}$ ratios $(\sim 70)$ to be characteristic for marine-snow-rich waters of the Northern Adriatic Sea. Concurrently, relatively high rates of PER $(\sim 80 \%)$ were obtained for free-living phytoplankton, while marinesnow-attached phytoplankton exhibited much lower PER rates $(\sim 30 \%)$ under a more balanced $\mathrm{N}$ :P ratio of the inorganic nutrient pool (N:P = 13) (Kaltenböck \& Herndl 1992). We have thus raised the hypothesis that the excessive PER produced under severe P limitation of exponentially growing phytoplankton is not utilized efficiently by bacteria and hence accumulates in the water column.

Mechanisms of DOM release by phytoplankton include active release (Fogg 1983) and passive permeation (Bjørnsen 1988), cell death and lysis, release during feeding by heterotrophs (Lampert 1978) and virus-induced lysis (Suttle et al. 1990). In our study, active release and passive permeation were assumed to be mainly responsible for exudation. Sharp (1977) pointed out that such studies are particularly susceptible to experimental error. Methodological errors, 
Table 5. Relationship between extracellular enzymatic activity ( $\alpha$ - and $\beta$-glucosidase activity) and dissolved free amino acids (DFAA) under different N:P ratios. An exponential model, $y=\mathrm{e}^{c+b_{1} x}$, fit the data best; data from exponential and stationary phase are pooled

\begin{tabular}{|c|c|c|c|c|c|}
\hline $\mathrm{N}: \mathrm{P}$ ratio & c & $b_{1}$ & $\mathrm{r}^{2}$ & $\mathrm{n}$ & $\mathrm{p}$ \\
\hline \multicolumn{6}{|c|}{$\alpha$-Glucosidase } \\
\hline 5 & 0.384 & 0.01 & 0.89 & 7 & $<0.001$ \\
\hline 16 & 1.093 & 0.00 & 0.00 & 7 & $>0.2$ \\
\hline 100 & 0.253 & 0.00 & 0.01 & 7 & $>0.2$ \\
\hline \multicolumn{6}{|c|}{$\beta$-Glucosidase } \\
\hline 5 & 0.503 & 0.01 & 0.92 & 7 & $<0.001$ \\
\hline 16 & 0.871 & 0.01 & 0.08 & 7 & $>0.2$ \\
\hline 100 & 0.246 & 0.00 & 0.01 & 7 & $>0.2$ \\
\hline
\end{tabular}

such as mechanical breakage of cells during filtration (Arthur \& Rigler 1967) and contamination with organic ${ }^{14} \mathrm{C}$, are regarded as serious problems in ${ }^{14} \mathrm{C}$ measurements of primary productivity and extracellular release. On the other hand, dense cultures and culture conditions in general are artificial and might give misleading results. We tried to avoid these problems by using low vacuum pressure $(<20 \mathrm{mbar})$ and adding inorganic nutrients into the seawater media comparable to those found under natural conditions (Table 1, $\sum \mathrm{N}_{\text {inorg. }} 4 \mu \mathrm{M}, \mathrm{PO}_{4} 0.1 \mu \mathrm{M}$; Karner et al. 1992). In our study, we inoculated Chaetoceros affinis batch cultures with natural bacterial consortia and allowed them to grow under different $\mathrm{N}: \mathrm{P}$ ratios. While we are aware of the fact that bacterial species composition might change during the course of incubation we have chosen this approach to more closely reflect natural conditions, where phytoplankton and bacteria are competing for available nutrients (Thingstad 1987). In our study, PER produced by phytoplankton might be immediately taken up by bacteria (Nalewajko \& Schindler 1976, Jensen 1983), since our cultures were not axenic. Underestimates of the actual PER due to concurrent uptake by heterotrophs are reported to range between 1 and $20 \%$ (Iturriaga \& Hoppe 1977 , Chróst \& Faust 1983). In contrast, Sharp (1977) found no significant difference in exudation comparing PER of axenic cultures with PER of phytoplankton cultures with bacteria inoculated. Despite these uncertainties we consider our percentages of PER (range: 15 to $39 \%$ of total primary production; Table 2) as conservative estimates.

Increased PER due to nutrient deficiency has been reported from laboratory cultures (Ignatiades \& Fogg 1973, Myklestad 1977, Watanabe 1980) and natural waters (Anderson \& Zeutschel 1970, Thomas 1971, Berman \& Holm-Hansen 1974, Larsson \& Hagström 1982, Kaltenböck \& Herndl 1992) and has been inter- preted as an overflow reaction of the phytoplankton (Fogg 1983). Therefore, we conducted experiments to simulate the effects of nutrient limitations on the quality of PER with respect to its bacterial utilization. We assumed phytoplankton to be nitrogen-limited in primary production when grown in a $\mathrm{N}: \mathrm{P}=5$ medium. Phytoplankton grown in the $\mathrm{N}: \mathrm{P}=16$ medium were assumed to reflect a balanced nutrient regime (Redfield et al. 1963), while P-limited primary production was supposed to occur in the $\mathrm{N}: \mathrm{P}=100$ medium.

Our results indicate a 2 -fold higher PER in severely P-limited ( $\mathrm{N}: \mathrm{P}=100)$ phytoplankton compared to phytoplankton grown under balanced conditions ( $\mathrm{N}: \mathrm{P}=16$ medium) in the exponential phase. $\mathrm{N}$-limited primary production ( $\mathrm{N}: \mathrm{P}=5)$, though $\mathrm{N}$ limitation was not as severe as $\mathrm{P}$ limitation in our study, still exhibited about

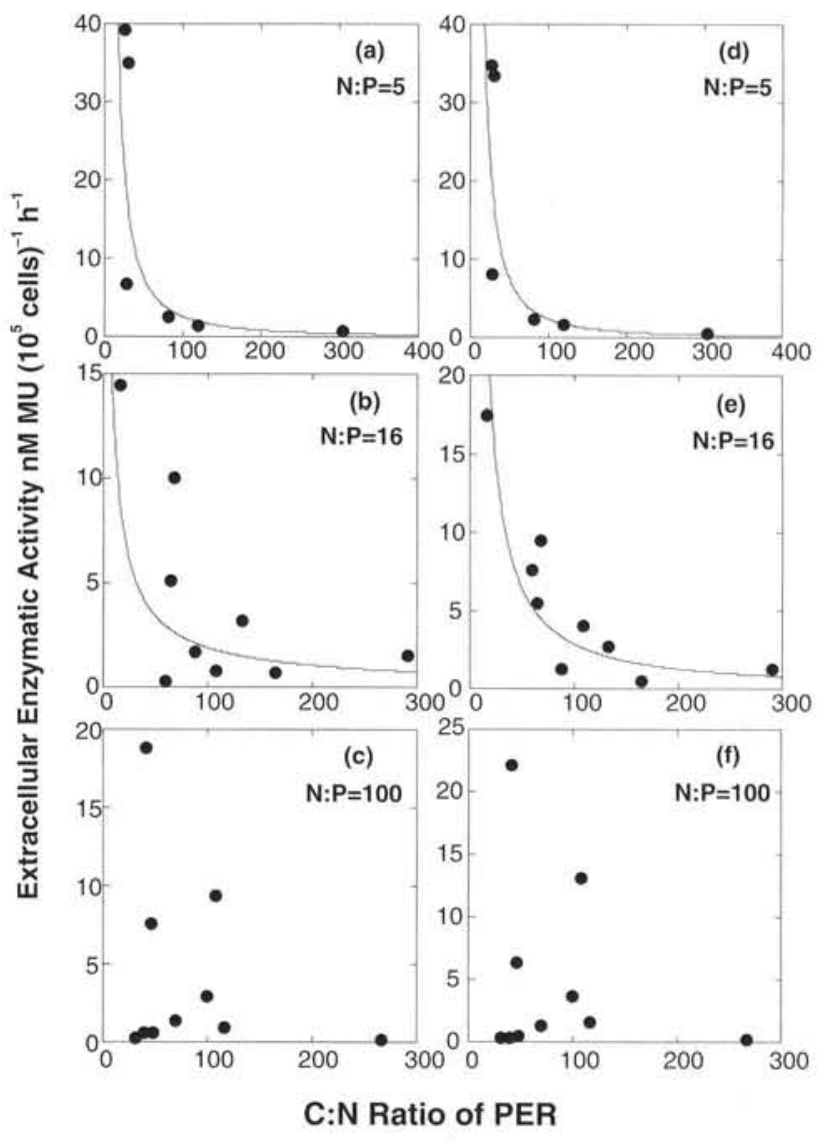

Fig. 5. Relationship between $\alpha$ - (a to $\mathrm{c}$ ) and $\beta$ - (d to f) glucosidase activity and $\mathrm{C}: \mathrm{N}$ ratio of $\mathrm{MCHO}+\mathrm{DFAA}$-derived PER under varying $\mathrm{N}$ : P ratios. Data from exponential and stationary phases are pooled. An exponential function fit the data best: (a) $y=\exp (4.593-0.046 x), \mathrm{r}^{2}=0.62, \mathrm{p}<0.05$; (b) $y=$ $\exp (3.036-0.022 x), \mathrm{r}^{2}=0.66, \mathrm{p}<0.01 ;$ (c) $y=\exp (1.880-$ $0.006 x), \mathrm{r}^{2}=0.34, \mathrm{p}=0.05$; (d) $y=\exp (4.318-0.039 x), \mathrm{r}^{2}=$ $0.65, \mathrm{p}<0.05$; (e) $y=\exp (3.196-0.020 x), \mathrm{r}^{2}=0.89, \mathrm{p}<0.001$; (f) $y=\exp (1.916-0.004 x), \mathrm{r}^{2}=0.031, \mathrm{p}<0.05$; where $y$ is EEA and $x$ is the $C: N$ ratio of PER 
$30 \%$ higher PER than phytoplankton under balanced nutrient supply. Decreasing differences in the amount of PER of phytoplankton in the stationary phase was due to increased release rates of phytoplankton grown in the $\mathrm{N}: \mathrm{P}=5$ and $\mathrm{N}: \mathrm{P}=16$ media. In terms of carbon, phytoplankton under P-limited conditions released highest PER in the exponential phase, while phytoplankton under balanced growth and under $\mathrm{N}$-limited conditions exhibited highest PER in the stationary phase (Table 2).

In our cultures the concentration of MCHO (2 to $5 \mu \mathrm{M})$ was in the upper range of concentrations reported from the Northern Adriatic Sea ( 0.5 to $2 \mu \mathrm{M}$; Karner et al. 1992) while the concentrations of DFAA $(130$ to $300 \mathrm{nM})$ were in the lower range of values for the Northern Adriatic Sea (140 to 2010 nM; Karner et al. 1992, Müller-Niklas et al. 1994). Normalized to phytoplankton biomass, $\mathrm{CHO}$ and DFAA concentrations in the media decreased from exponential to stationary phase under $\mathrm{N}$ limitation and, though not as pronounced, under balanced growth (Fig. 3); this net decline might indicate a more efficient bacterial utilization of stationary-phase PER. In contrast, $\mathrm{CHO}$ and DFAA increased remarkably in the P-limited medium from exponential to stationary growth, accordingly indicating inefficient microbial utilization. Our findings correspond with those of Myklestad \& Haug (1972), who found the most pronounced increase in extracellular polysaccharides in cultures of Chaetoceros affinis under P-limited conditions.

Our calculations of the $\mathrm{C}: \mathrm{N}$ ratio of the $\mathrm{MCHO}$ and the DFAA fractions of the PER can only be regarded as a rough estimate of the C:N ratio of the readily available substrate since proteins and $\mathrm{PCHO}$ are not included in these calculations. According to our results (mean C:N ratio of $\sim 100: 1$ ), nitrogen could be the limiting nutrient for bacterial growth in all treatments and growth phases. As reported by Zweifel et al. (1993), in situ dissolved organic matter in surface waters of the Baltic Sea with a C:N ratio of 25:1 was far from ideal as a bacterial substrate.

Mean values of potential growth yields of bacteria incubated with PER derived from different nutrient conditions and growth phases ranged between 22 and $56 \%$ (Table 4 ). Similar results ( $43 \%$ ) in $24 \mathrm{~h}$ incubations were obtained by Cole et al. (1982). Jensen (1983), using a prokaryotic inhibitor (Streptomycin) during phytoplankton growth, found bacterial removal of the total amount of released matter to range between 39 and $91 \%$ and to be $\sim 40 \%$ in long- ( 3 to $159 \mathrm{~h})$ and short-term ( 0.5 to $3.5 \mathrm{~h})$ experiments, respectively. Recently, Coffin et al. (1993) obtained growth yields on natural substrates ranging from 16 to $43 \%$. Thus our data are well within the range of growth yields reported in the literature.
High $\alpha$ - and $\beta$-glucosidase in the $\mathrm{N}: \mathrm{P}=5$ and $\mathrm{N}: \mathrm{P}=16$ media (Fig. 4) lets us suggest that the pool of readily utilizable DOM is limited under these conditions as indicated also by lower bacterial densities. We thus assume that high EEA on a per cell basis reflects enhanced cleavage of macromolecular products (Chróst 1989). In the $\mathrm{N}: \mathrm{P}=100$ medium, on the other hand, high $\mathrm{MCHO}$ and DFAA concentrations indicate that those organic nutrient species are not taken up efficiently, reflecting limited substrate availability other than organic carbon or nitrogen.

\section{Interaction between PER and bacteria under contrasting nutrient regimes}

To explain the fluctuations in $\mathrm{CHO}$ and DFAA concentrations measured in different treatments and phases of phytoplankton growth we propose the following scenario (Fig. 6). Our assumptions are (1) that the PER pool mainly consists of carbohydrates (MCHO, PCHO) and amino acids (DFAA, DCAA) (Myklestad et al. 1989) and (2) there are no other sources for bacterial growth than the added PER and inorganic nutrients. Therefore, under our experimental conditions, bacterial growth yield is likely to be dependent on the organic carbon of the PER added and the ratio of available C:N:P.

Under $\mathrm{N}$-limited conditions ( $\mathrm{N}: \mathrm{P}=5)$, DFAA availability probably limits bacterial activity. As the residual DFAA pool is rather small, it is suggested that proteins are cleaved by bacterial extracellular proteases; we assume a tight coupling of protein hydrolysis and amino acid uptake under these conditions (Hoppe 1991).

We calculated a C:N ratio for DFAA of about 2.9 and assumed that of bacteria to be about 5 (Goldman et al. 1987, Lee \& Fuhrman 1987); thus it is likely that the additional carbon demand necessary for bacterial growth is met by uptake of MCHO. Furthermore, high hydrolysis activity of $\alpha$-and $\beta$-glucosidase under $\mathrm{N}$-limited conditions (Fig. 4a) might indicate this elevated carbon demand. Fig. 5 indicates decreasing enzymatic activity of $\alpha$ - and $\beta$-glucosidase with an increasing $C: N$ ratio of PER. Since $C: N$ ratios were calculated from DFAA carbon, DFAA nitrogen and MCHO carbon (see also 'Materials and methods'), an increase in the $\mathrm{C}: \mathrm{N}$ ratio should reflect increased availability of utilizable carbon, as also indicated by a positive correlation detectable between glucosidase activity and DFAA (Table 5). Thus, it is reasonable to assume that bacterial growth is controlled by hydrolysis activity of proteins and the $\mathrm{PCHO}$ pool under Nlimited conditions (Fig. 6). Once these macromolecular components are cleaved into their monomeric 


\section{$\mathrm{N}$-Limitation}

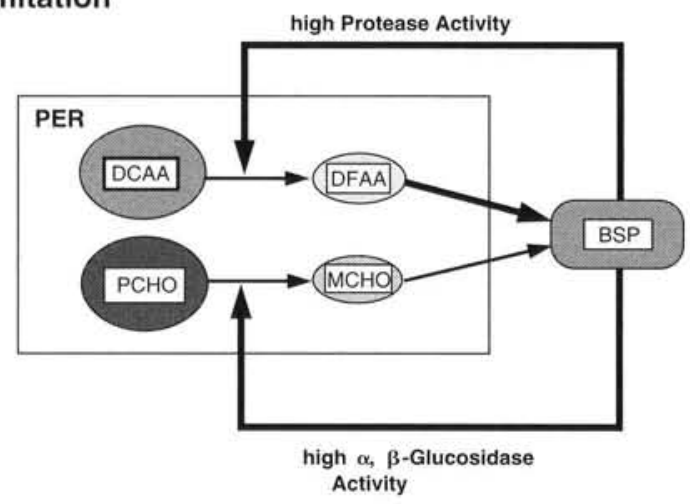

\section{P-Limitation}

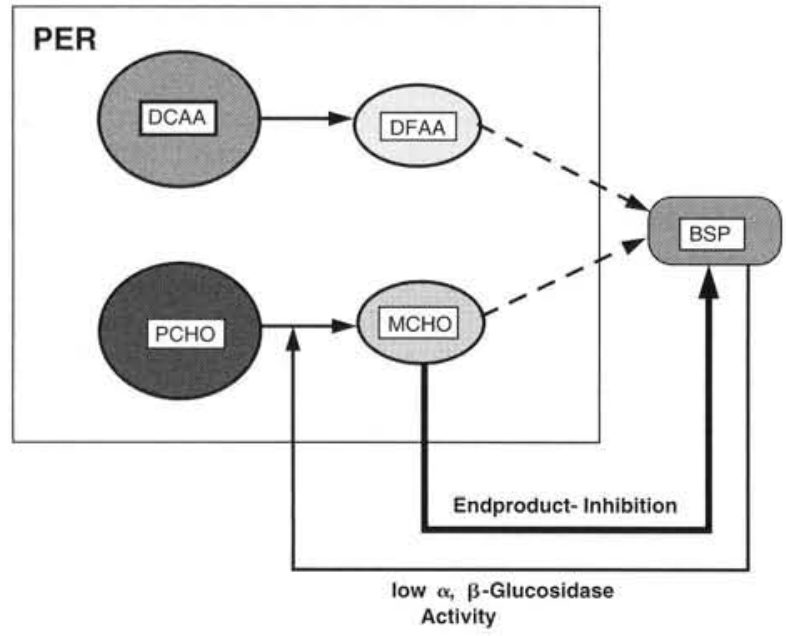

Fig. 6. Conceptual model of bacterial interactions with simple and complex amino acids and carbohydrates and regulatory mechanisms of extracellular enzymatic activity under $\mathrm{N}$ and $\mathrm{P}$ limitation. DFAA: dissoved free amino acids; PCHO: polymeric carbohydrates; MCHO: monomeric carbohydrates; BSP: bacterial secondary production. Further explanation given in text

constituents (DFAA, MCHO) they are taken up efficiently by the bacterial community as indicated by low DFAA and MCHO concentrations detectable in the $\mathrm{N}$-limited regime (Fig. 6).

Under P-limited conditions of PER production, however, the scenario appears to be quite different. Severely P-limited phytoplankton releases large amounts of organic compounds (Table 2). The high concentrations of $\mathrm{MCHO}$ and DFAA (Fig. 3) present in the media point to an inefficient utilization by bacteria (Fig. 6). Furthermore, high endproduct concentrations (glucose in this case) might inhibit glucosidase activity as shown by Chróst (1991) and indicated also in this study (Fig. 4). Limiting inorganic and organic phosphorus availability appears to have a severe impact on bacterial metabolism. Low uptake rates of labile organic compounds are indicated by increasing concentrations of DFAA and $\mathrm{MCHO}$ in the stationary phase (Table 3). Thus other substances are likely to control bacterial growth under these conditions; most probably phosphorus availability controls uptake of carbohydrates and DFAA.

In summary, our results show that P-limited phytoplankton release a higher amount of PER in the exponential phase which is not utilized efficiently by heterotrophic bacteria. Thus, a large stock of organic compounds originating from both phytoplankton and bacteria might accumulate in the water. Particle aggregation induced by low turbulence of the water column and adsorption phenomena are most likely enhanced by large amounts of colloidal material present in the water column. Extrapolating our results to the Northern Adriatic Sea, we might conclude that elevated PER by phytoplankton is provoked by severe P limitation. Due to its inefficient utilization by heterotrophic bacteria, this PER remains in the water column for a prolonged period of time and might coagulate and eventually form mucilage. Rapid adsorption of this labile PER onto colloidal matter most likely prevents us from detecting this pool in the DOM fraction under in situ conditions.

Acknowledgements. We thank our colleagues at the Department of Marine Biology, University of Vienna, as well as the staff of the Institute 'Ruder Boskovic', Center for Marine Research at Rovinj, Croatia. T. J. Battin helped with statistics. This study was supported by the Austrian Science Foundation (FWF P-8608-BI0). The work is part of the fulfillment of the requirements towards a M.Sc. degree at the University of Vienna by I.O.

\section{LITERATURE CITED}

Alldredge, A. L., Silver, M. W. (1988). Characteristics, dynamics and significance of marine snow. Prog. Oceanogr. 20: $41-82$

Anderson, G. C., Zeutschel, R. P. (1970). Release of dissolved organic matter by marine phytoplankton in coastal and offshore areas of the northeast Pacific Ocean. Limnol. Oceanogr. 15: 402-407

Arthur, C. R., Rigler, F. H. (1967). A possible source of error in the ${ }^{14} \mathrm{C}$ method of measuring primary productivity. Limnol. Oceanogr. 12: 121-124

Bell, W. H. (1983). Bacterial utilization of algal extracellular products. 3 . The specificity of algal-bacterial interaction. Limnol. Oceanogr. 28: 1131-1143

Berman, R., Holm-Hansen, O. (1974). Release of photoassimilated carbon as dissolved organic matter by phytoplankton. Mar. Biol. 28: 305-310

Bjørnsen, P. K. (1988). Phytoplankton exudation of organic matter: why do healthy cells do it? Limnol. Oceanogr. 33: 151-154

Burney, C. M., Sieburth, J. McN. (1977). Dissolved carbohydrates in seawater. II. A spectrophotometric procedure for total carbohydrate analysis and polysaccharide estimation. Mar. Chem. 5: 15-28 
Chróst, R. J. (1989). Characterization and significance of $\beta$-glucosidase activity in lake water. Limnol. Oceanogr. 34: 660-672

Chróst, R. J. (1991). Environmental control of the synthesis and activity of aquatic microbial ectoenzymes. In: Microbial enzymes in aquatic environments. Springer, New York, p. $29-54$

Chróst, R. J., Faust, M. A. (1983). Organic carbon release by phytoplankton: its composition and utilization by bacterioplankton. J. Plankton Res. 5: 477-493

Cole, R. J., Likens, G. E., Strayer, D. L. (1982). Photosynthetically produced dissolved organic carbon: an important carbon source for planktonic bacteria. Limnol. Oceanogr. 27: $1080-1090$

Coffin, R. B., Connolly, J. P., Harris, P. S. (1993). Availability of dissolved organic carbon to bacterioplankton examined by oxygen utilization. Mar. Ecol. Prog. Ser. 101: 9-22

Degobbis, D. (1989). Increased eutrophication of the Northern Adriatic Sea. Second Act. Mar. Pollut. Bull. 20: 452-457

Fogg, G. E. (1966). The extracellular products of algae. Oceanogr, mar. Biol. A. Rev, 4: 195-212

Fogg, G. E. (1983). The ecological significance of extracellular products of phytoplankton photosynthesis. Botanica mar. 26: $3-14$

Fuhrman, J. A., Eppley, R. W., Hagström, A., Azam, F. (1985). Diel variations in bacterioplankton, phytoplankton and related parameters in the Southern California Bight. Mar. Ecol. Prog. Ser. 27: 9-20

Goldman, J. C., Caron, D. A., Dennett, M. R. (1987). Regulation of gross growth efficiency and ammonium regeneration in bacteria by substrate C:N ratio. Limnol. Oceanogr. 32: $1239-1252$

Guillard, R. R. L., Ryther, J. H. (1962). Studies of marine planktonic diatoms. I. Cyclotella nana Hustedt, and Detonula confervacea (Cleve) Gran. Can. J. Microbiol. 8: 229-239

Hellebust, J. A. (1974). Extracellular products. In: Stewart, W. D. P. (ed.) Algal physiology and biochemistry. Blackwell, Oxford, p. 838-863

Herndl, G. J. (1988). Ecology of amorphous aggregations (marine snow) in the Northern Adriatic Sea. II. Microbial density and activity in marine snow and its implication to overall pelagic processes. Mar. Ecol. Prog. Ser. 48: 265-275

Herndl, G. J., Malacic, V. (1987). Impact of the pycnocline layer on bacterioplankton: diel and spatial variations in microbial parameters in the stratified water column of the Gulf of Trieste (Northern Adriatic Sea). Mar. Ecol. Prog. Ser. 38: 295-303

Hobbie, J. E., Daley, R. J., Jasper, S. (1977). Use of nucleporefilters for counting bacteria by fluorescence microscopy. Appl, environ. Microbiol. 33: 1225-1228

Hoppe, H.-G. (1983). Significance of exoenzymatic activities in the ecology of brackish water: measurements by means of methylumbelliferyl substrates. Mar. Ecol. Prog. Ser. 11: 299-308

Hoppe, H.-G. (1991), Microbial extracellular enzyme activity: a new key parameter in aquatic ecology. In: Microbial enzymes in aquatic environments. Springer, New York, p. $60-80$

Hoppe, H.-G., Kim, S., Gocke, K. (1988). Microbial decomposition in aquatic environments: combined process of extracellular enzyme activity and substrate uptake. Appl. environ. Microbiol. 54: 784-790

Ignatiades, L., Fogg, G. E. (1973). Studies on the factors affecting the release of dissolved organic matter by Skeletonema costatum (Greville) Cleve in culture. J. mar. biol. Ass. U.K. 53: 937-956
Iturriaga, R., Hoppe, H.-G. (1977). Observations of heterotrophic activity on photoassimilated organic matter. Mar. Biol. 40: 101-108

Iturriaga, R., Zsolnay, A. (1983). Heterotrophic uptake and transformation of phytoplankton extracellular products. Botanica mar. 26: 375-381

Jensen, L. M. (1983). Phytoplankton release of extracellular organic carbon, molecular weight composition, and bacterial assimilation. Mar. Ecol. Prog. Ser. 11: 39-48

Johnson, K. M., Sieburth, J. McN. (1977). Dissolved carbohydrates in seawater. I. A precise spectrophotometric analysis for monosaccharides. Mar. Chem. 5: 1-13

Kaltenböck, E., Herndl, J. G. (1992). Ecology of amorphous aggregations (marine snow) in the Northern Adriatic Sea. IV. Dissolved nutrients and the autotrophic community associated with marine snow. Mar. Ecol. Prog. Ser. 87: $147-159$

Karner, M., Fuks, D., Herndl, G. J. (1992). Bacterial activity along a trophic gradient. Microb. Ecol. 24: 243-257

Kirchman, D. L. (1992). Incorporation of thymidine and leucine in the subarctic Pacific: application to estimating bacterial production. Mar. Ecol. Prog. Ser. 82: 301-309

Lampert, W. (1978). Release of dissolved organic carbon by grazing zooplankton. Limnol. Oceanogr. 23: 831-834

Lancelot, C. (1983). Factors affecting phytoplankton extracellular release in the Southern Bight of the North Sea. Mar. Ecol. Prog. Ser. 12: 115-121

Larsson, U., Hagström, A. (1982). Fractionated phytoplankton primary production. Exudate release and bacterial production in a Baltic eutrophication gradient. Mar. Biol. 16: $55-70$

Lee, S., Fuhrman, J. A. (1987). Relationships between biovolume and biomass of naturally derived marine bacterioplankton. Appl. environ. Microbiol. 53: 1298-1303

Lignell, R. (1990). Excretion of organic carbon by phytoplankton: its relation to algal biomass, primary productivity and bacterial secondary productivity in the Baltic Sea. Mar. Ecol. Prog. Ser. 68: 85-99

Lignell, R. (1992). Problems in filtration fractionation of ${ }^{14} \mathrm{C}$ primary productivity samples. Limnol. Oceanogr. 37 : $172-178$

Mague, T. H., Friberg, E., Hughes, D. J., Morris, I. (1980) Extracellular release of carbon by marine phytoplankton; a physiological approach. Limnol. Oceanogr. 25: 262-279

Mopper, K., Lindroth, P. (1982). Diel depth variations in dissolved free amino acids and ammonium in the Baltic Sea determined by shipboard HPLC analysis. Limnol. Oceanogr. 27: 336-347

Müller-Niklas, G., Schuster, S., Kaltenböck, E., Herndl, G. J. (1994). Organic content and bacterial metabolism in amorphous aggregations of the northern Adriatic Sea. Limnol. Oceanogr. 39: 58-68

Myklestad, S. (1977). Production of carbohydrates by marine planktonic diatoms. II. Influence of the N:P ratio in the growth medium on the assimilation ratio, growth rate, and production of cellular and extracellular carbohydrates by Chaetoceros affinis var. willei (Gran) Hustedt and Skeletonema costatum (Grev.) Cleve. J. exp. mar. Biol. Ecol. 29: $161-179$

Myklestad, S., Haug, A. (1972). Production of carbohydrates by the marine diatom Chaetoceros affinis var. willei (Gran) Hustedt. I. Effect of the concentration of nutrients in the culture medium. J. exp. mar. Biol. Ecol. 9: 125-136

Myklestad, S., Holm-Hansen, O., Varum, K. M., Volcani, B. E. (1989). Rate of release of extracellular amino acids and carbohydrates from the marine diatom Chaetoceros affinis. J. Plankton Res. 11: 763-773 
Nalewajko, C., Schindler, D. W. (1976). Primary production, extracellular release, and heterotrophy in two lakes in the ELA, northwestern Ontario. J. Fish. Res. Bd Can. 33: $219-226$

Pakulski, J. D., Benner, R. (1992). An improved method for the hydrolysis and MBTH analysis of dissolved and particulate carbohydrates in seawater. Mar. Chem. 40: $143-160$

Parsons, T., Maita, Y., Lalli, C. (1984). A manual of chemical and biological methods for seawater analysis. Pergamon Press, Oxford

Redfield, A. C., Ketchum, B. H., Richards, F. A. (1963). The influence of organisms on the composition of sea water. In: Hill, M. N. (ed.) The sea. Wiley, New York, p. 26-77

Saunders, G. W. (1976). Decomposition of freshwater. In: Anderson, J. M., Macfadyen, A. (eds.) The role of terrestrial and aquatic organisms in decomposition processes. 17 th Symposium of the British Ecology Society. Blackwell, Oxford, p. 341-373

Sell, A. F., Overbeck, J. (1992). Exudates: phytoplanktonbacterioplankton interactions in Plusssee. J. Plankton Res. 14: $1199-1215$

Sharp, J. H. (1977). Excretion of organic matter by marine phytoplankton: do healthy cells do it? Limnol. Oceanogr. 22: $381-399$

Simon, M., Azam, F. (1989). Protein content and protein

This article was submitted to the editor synthesis rates of planktonic marine bacteria. Mar. Ecol. Prog. Ser. 51: 201-213

Suttle, C. A., Chan, A. M., Cottrell, M. T. (1990). Infection of phytoplankton by viruses and reduction of primary production. Nature 347: 467-469

Thingstad, T. F. (1987). Utilization of N, P and organic C by heterotrophic bacteria. I. Outline of a chemostat theory with a consistent concept of 'maintenance' metabolism. Mar. Ecol. Prog. Ser. 35: 99-109

Thomas, J. P. (1971). Release of dissolved organic matter from natural populations of marine phytoplankton. Mar. Biol. 11: $317-323$

Watanabe, Y. (1980). A study of the excretion and extracellular products of natural phytoplankton in Lake Nakanuma, Japan. Int. Revue ges. Hydrobiol. 65: 809-834

Wiebe, W. J., Smith, D. F. (1977). Direct measurement of dissolved organic carbon release by phytoplankton and incorporation by microheterotrophs. Mar. Biol. 42: 213-233

Wilkinson, L. (1990). SYSTAT: the system for statistics. SYSTAT, Inc., Evanston, IL

Wolter, K. (1982). Bacterial incorporation of organic substances released by natural phytoplankton populations. Mar. Ecol. Prog. Ser. 7: 287-295

Zweifel, U. L., Norrman, B., Hagstrom, A. (1993). Consumption of dissolved organic carbon by marine bacteria and demand for organic nutrients. Mar. Ecol. Prog. Ser. 101: 23-32

Manuscript first received: May 16, 1994

Revised version accepted: September 22, 1994 